\title{
A nem denaturált 2-es típusú kollagén hatása az arthrosisra
}

\author{
Sütő Gábor dr. \\ Pécsi Tudományegyetem, Általános Orvostudományi Kar, II. Belgyógyászati Klinika és Nephrológiai, \\ Diabetológiai Centrum, Pécs
}

\begin{abstract}
Az arthrosis az ízületeket alkotó porc, csont és a környező lágy részek leépülésével járó betegség. A betegség jelentős fájdalommal jár, progresszív, az ízület strukturális átalakulását és ennek következtében jelentős funkcióvesztést és életminőség-romlást okoz. Kialakulásában immunológiai gyulladásos folyamatok is szerepet játszanak, amelyek befolyásolása lehetőséget ad nemcsak tüneti kezelésre, hanem betegségmódosító terápia kialakítására is. A nem denaturált 2-es típusú kollagén oralis alkalmazása szisztémás toleranciát hoz létre, ami a proinflammatoricus folyamatok gátlása és az antiinflammatoricus hatások erősítése révén új lehetőség az immunmodulációra. A klinikai vizsgálatok a betegeknél a fájdalom jelentős csökkenéséról, a mozgásszervek funkciójának javulásáról számolnak be, és a kezelés egészséges ízületben is nyújthat védelmet a mechanikus stressz okozta ízületi károsodással szemben.

Orv Hetil. 2021; 162(37): 1481-1484.
\end{abstract}

Kulcsszavak: arthrosis, arthritis, betegségmódosító kezelés, chondroprotectio, 2-es típusú nem denaturált kollagén

\section{Undenatured type II collagen in the treatment of osteoarthritis}

Osteoarthritis is a disease of the cartilage, bone and surrounding soft tissues that make up the joints. The disease is associated with significant pain, it is progressive, causing structural transformation of the joint and, as a result, significant loss of function and deterioration in the quality of life. Immunological inflammatory processes also play a role in its development, the influence of which allows not only symptomatic treatment, but also the development of disease-modifying therapy. Oral administration of undenatured type II collagen creates systemic tolerance, which is a new opportunity for immunomodulation by inhibiting proinflammatory processes and enhancing anti-inflammatory effects. Clinical trials have reported significant reduction in pain, improved musculoskeletal function in patients, and the therapy may provide protection against joint damage caused by mechanical stress in healthy joints.

Keywords: arthrosis, arthritis, disease-modifying therapy, chondroprotection, undenatured type II collagen

Sütő G. [Undenatured type II collagen in the treatment of osteoarthritis]. Orv Hetil. 2021; 162(37): 1481-1484.

(Beérkezett: 2021. június 22.; elfogadva: 2021. július 9.)

\begin{abstract}
Rövidítések
$\mathrm{COMP}=($ cartilage oligomeric matrix protein $)$ porc oligomer mátrixprotein; $\mathrm{ECM}$ = extracelluláris mátrix; $\mathrm{G}$ = glükózamin; $\mathrm{Ihh}=$ (Indian hedgehog) jelátviteli út; IL = interleukin; $\mathrm{K}=$ kondroitin; TGF $\beta /$ Smad $=$ (transforming growth factor beta $)$ transzformáló növekedési faktor-béta és jelátviteli rendszere; $\mathrm{T}_{\mathrm{H}} \mathrm{l}=(\mathrm{T}$ helper cell $\mathrm{l}) \mathrm{l}$-es típusú segítő T-sejt; $\mathrm{T}_{\mathrm{H}} 2=(\mathrm{T}$ helper cell 2) 2-es típusú segítő T-sejt; T-reg = regulatorikus T-sejt; UC-II = (undenatured type II collagen) 2 -es típusú nem denaturált kollagén; VAS = vizuális analóg skála; Wnt = (wingless $/$ integrated) jelátviteli út; WOMAC $=$ (Western Ontario and McMaster Universities Arthritis Index) a Western Ontario és a McMaster Egyetem osteoarthritis-indexe
\end{abstract}

Az arthrosis összetett betegség, amely elsősorban az ízületi porcot, az alatta fekvő csontot és az ízületeket körülvevő lágy részeket érinti, az angolszász irodalomban osteoarthritisnek nevezik. A rheumatoid arthritisszel párban a két leggyakoribb ízületi megbetegedés egyike. Magyarországon a radiológiailag megerősített térdízületi arthrosis előfordulása $13,3 \%$ a teljes népességben, az előrehaladott arthrosisé 2,9\% volt egy 10000 föt érintő felmérésben [1]. Az arthrosis a fájdalom mellett az ízület instabilitásához, megváltozott múködéséhez vezet, gyakran áll rokkantság hátterében. Kialakulásához sok tényező együttmúködése szükséges, a pontos mechaniz- 
mus nem is ismert. Ezért oki terápia jelenleg nem áll rendelkezésre, a konzervatív kezelés elsősorban a fájdalom csillapítását célozza, valamint gyulladáscsökkentésre korlátozódik. Az előrehaladottabb esetekben ízületi protézis beültetése lehet a végső megoldás.

\section{$\mathrm{Az}$ arthrosis kialakulása}

Az ízületek felszínét 2-4 mm vastag hialinporc fedi. A legtöbb szövettől eltérően az ízületi porcban nincsenek erek, idegek és nyirokerek. A porcot sürü extracelluláris mátrix (ECM) képezi, amelyben a chondrocyták, a specializált porcsejtek elszórtan helyezkednek el. Az ECM elsősorban vízből, 2-es típusú kollagénből és proteoglikánokból áll, más, nem kollagén fehérjék és glikoproteinek kisebb mennyiségben vannak jelen. Ezek az összetevők együttesen segítik a víz visszatartását, ami az ECM rendkívüli rugalmasságának alapja [2]. Az arthrosisra sokáig úgy tekintettünk, mint pusztán a porc mechanikus degenerációjára, az életkor velejárójára. A porc és az alatta fekvő csont gyulladását azonban a környezô lágy részek megbetegedése kíséri, sokszor szisztémás gyulladásos eltérésekkel [3]. A porchomeostasis felborulását sok tényező segíti elő: a mechanikus terhelés mellett az életkor előrehaladása [4], anyagcsere-betegségek $[5,6]$, ülő életmód, dohányzás, alkoholfogyasztás és az egészségtelen táplálkozás is [7]. A chondrocyták a porc szerkezetének és élettani múködésének kiemelt jelentőségú szabályozói [8]. A TGFß/Smad, Wnt/ $\beta$-katenin és Ihh jelátviteli rendszerek genetikai változásai megbontják a porc anabolikus és katabolikus folyamatainak egyensúlyát, kedvezve a porc- és a csontleépülésnek [8].

\section{$\mathrm{Az}$ arthrosis betegségmódosító kezelése}

A porc önmagában nagyon korlátozott regeneratív képességü, ezért a chondroprotectio lehetőségei - hogy a porcleépülést megakadályozzuk, a porc épülését serkentsük - nagyon korlátozottak [9]. Az arthrosis betegségmódosító szerei a chondrocyták anyagcseréjét és/vagy az ECM-degradációt igyekeznek befolyásolni. Ezek közé a szerek közé tartoznak az antiapoptotikus molekulák, a kaszpázgátlók, a glükózamin, a rizedronsav, a doxiciklin, a növekedési faktorok, a thrombocytadús plazma, a ciklooxigenáz-gátlók és a kondroitin-szulfát [9].

A kollagén alkalmazásának észszerüségét számos elméleti megfontolás és állatkísérletes megfigyelés támasztja alá. A kollagén parenteralis alkalmazásával indukált arthritis a rheumatoid arthritis egyik leggyakrabban vizsgált modellje [10]. A 2-es típusú nem denaturált kollagén (undenatured type II collagen, UC-II) per os adása azonban a proinflammatoricus citokinek (IL2, IL17) csökkent termelését, az antiinflammatoricus citokinek fokozott képződését eredményezi (IL4, TGFß), így szabályozva a Th1/Th2 és Th17/T-reg egyensúlyt [11]. Az UC-II per os alkalmazása a bélasszociált lymphoid szövetben T-reg-sejtek indukciójával szisztémás oralis

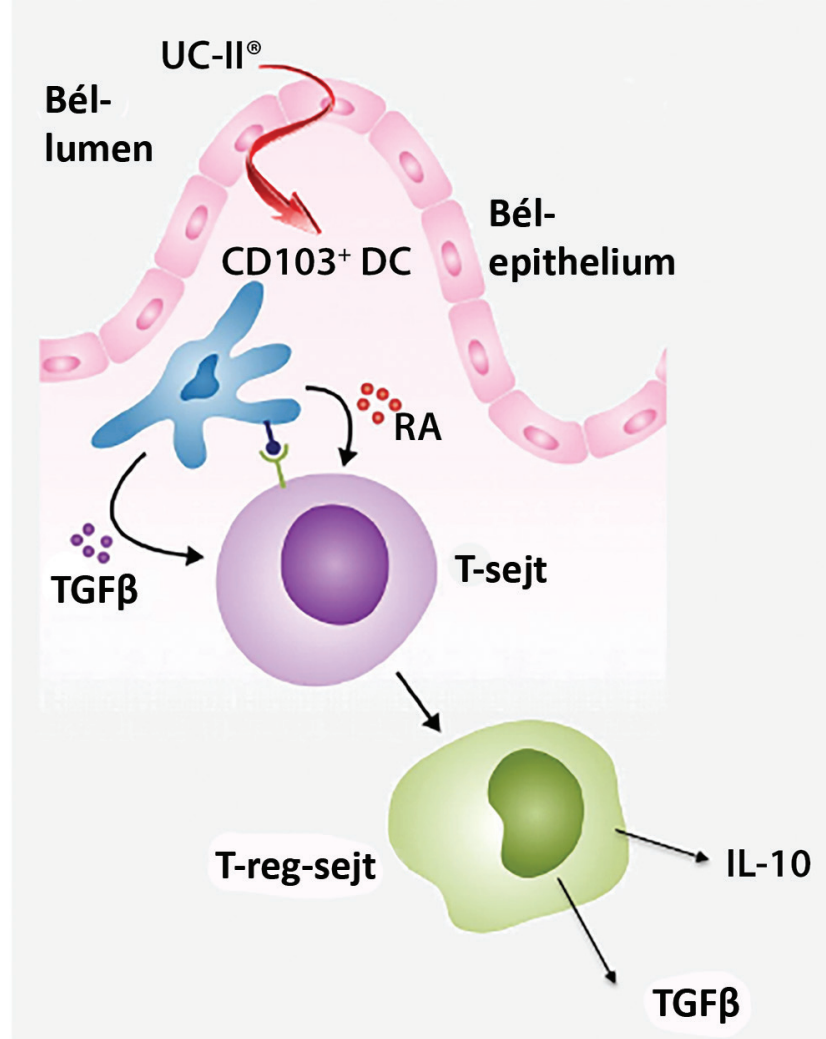

1. ábra Az UC-II per os alkalmazása a bélasszociált lymphoid szövetben
T-reg-sejtek aktivációjával, IL10- és TGFß-termeléssel sziszté-
más oralis toleranciát hoz létre. Az ábra reprodukciója a Sager
Pharma Kft. hozzájárulásával történt
IL = interleukin; TGF $\beta$ = transzformáló növekedési faktor-béta;
T-reg = regulatorikus T-sejt; UC-II = 2-es típusú nem denatu-
rált kollagén

toleranciát tud létrehozni, enyhíti a T-sejtek okozta porckárosodást [12] (1. ábra). Az alkalmazott kollagén minősége meghatározó, mivel a nem denaturált 2-es típusú tartja meg a térbeli szerkezetét, a megfelelő számú epitópot és így a biológiai aktivitását.

\section{Az UC-II alkalmazása a gyakorlatban}

Az első vizsgálat 60, rheumatoid arthritisben szenvedő betegnél történt 1993-ban. A duzzadt és érzékeny ízületek számában és a reggeli ízületi merevség időtartamában jelentős csökkenés volt észlelhető, 4 betegnél teljes remisszió jött létre [13]. Az UC-II-nek a rheumatoid arthritis kezelésében való hatásosságát igazolva további vizsgálat történt 5, ízületi fájdalomban szenvedő nőbetegnél. Ők a panaszaik alapján elsősorban arthrosisban szenvedtek, napi 10 mg UC-II-kezelést kaptak 42 napig. 4 beteg a fájdalom $15 \%$-os csökkenéséról számolt be mellékhatás nélkül [14]. 90 napos vizsgálatban 26, UC-II-vel és 26, glükózamin-hidroklorid és kondroitin-szulfát kombinációjával kezelt beteg klinikai adatait hasonlították össze. A Western Ontario and McMaster Universities Arthritis Index (WOMAC) [15], a Lequesne-pontszám 
[16] és a vizuális analóg skála (VAS) segítségével értékelték a kezelés hatását. A WOMAC-index három skálán a fájdalmat, a mozgásszervi merevséget és a fizikai teljesíto"képességet méri csípő- és térdízületi arthrosisban. A Lequesne-index a térdarthrosisban alkalmazott kezelések hatásosságának felmérésére szolgál, a fájdalom vagy diszkomfort erősségét, a maximális megtett távolságot és a mindennapi élet tevékenységei során nyújtott teljesítményt számszerúsíti. A betegek napi 40 mg UC-II-t kaptak, amely $10 \mathrm{mg}$ bioaktív UC-II-nek felelt meg. A glükózamin (G) adagja napi $1500 \mathrm{mg}$, a kondroitiné (K) $1200 \mathrm{mg}$ volt. Mindkét kezelési forma csökkentette a WOMAC-index értékét, de az UC-II-kezelés során 33\%kal, a G + K kezelés alatt 14\%-kal javult az index 90 nap után. A VAS esetében ezek az értékek $40 \%$ és 15,4\% voltak az UC-II javára. A Lequesne-index is az UC-II nagyobb hatásosságát mutatta, mivel 20,1\%-os csökkenés állt szemben a G + K 5,9\%-ával szemben. A mellékhatások előfordulásának gyakoriságát illetően jelentős különbség nem volt, az UC-II-csoportban 35 eset (11,4\%), a G + K csoportban 58 eset (23\%) fordult elő. Az UC-IIkezelteknél azonban a constipatio és a fejfájás volt gyakori, a $\mathrm{G}+\mathrm{K}$ kezelteknél puffadás, hasi fájdalom, bőrpír, vízretenció (szem körüli ödéma), csalánkiütés, fejfájás fordult elő [17]. Az előző vizsgálathoz hasonló elrendezésben 180 napon keresztül vizsgálták az UC-II $(40 \mathrm{mg}$ ) hatásosságát és tolerálhatóságát térdízületi arthrosisban placebóval és $\mathrm{G}+\mathrm{K}(1500 \mathrm{mg}$ és $1200 \mathrm{mg})$ kezeléssel összehasonlítva. Az UC-II-kezelt betegeknél jelentős csökkenés volt mind a WOMAC-indexben, mind a 3 alskálában, úgymint fájdalom, ízületi merevség, fizikai funkció [18]. Hasonlóképpen a VAS-érték és a Lequesneindex is alacsonyabb volt az UC-II-csoportban. Ebben a vizsgálatban a $\mathrm{G}+\mathrm{K}$ kezelés nem mutatott különbséget a placebóval kezeltekhez képest. A vizsgálat érdekessége, hogy az UC-II-re adott választ a kiindulási porc oligomer mátrixproteinre (cartilage oligomeric matrix protein, COMP) vonatkoztatva érzékenyítették. A kiindulási COMP-érték befolyásolta a kezelésre adott választ, a 285 $\mathrm{ng} / \mathrm{ml}$ feletti érték esetén a javulás mértéke nagyobb volt (43\% vs. 36\%) [18].

A kollagénkezelés hozzájárulhat a porc egészségéhez már akkor is, amikor nincs nyilvánvaló betegség, porckárosodás. 55 egészséges önkéntes kapott napi 40 mg UCII- vagy placebokezelést 120 napon keresztül [19]. Az UC-II-kezelteknél a térdnyújtás 7 fokot javult a kiindulási és a placebokezelt csoport 120 napos értékéhez képest. Ez utóbbi csoportban a térd nyújthatósága a kiinduláshoz képest semmit nem változott. Lépcsőzés során a fájdalom megjelenése $[2,8 \pm 0,5$ vs. 1,4 perc) és tetőzése $(6,39 \pm 0,5$ vs. $4,78 \pm 0,5$ perc $)$ az UC-II-kezelt csoportban később következett be, mint a kontrollszemélyeknél. A vizsgálat végén volt még egy különbség: az UC-II-kezelteknél 5, a placebót kapók között l fő volt, aki nem jelzett fájdalmat még a 10 perces terhelés végén sem. Egyik csoportban sem észleltek mellékhatást [19].

\section{Az UC-II klinikai alkalmazhatósága}

A gyulladásos eredetú ízületi betegségek kezelése a mai napig sok kihívást jelent a gyakorlatban. Az arthritisek jellegzetessége a synovium gyulladása, amelynek kezelésében számos hagyományos, nem biológiai és biológiai betegségmódosító szer áll rendelkezésre. Az arthrosis kezelése sok tekintetben korlátozott. A gyakorlatban elsősorban fájdalomcsillapító és gyulladáscsökkentő gyógyszereket alkalmazunk. A hosszabb távú megoldást a betegségmódosító kezelések alkalmazása fogja jelenteni a porcdestrukció lassítása, a porcregeneráció elősegítése révén. Ismereteink bővülésével egyre nyilvánvalóbbá vált, hogy az arthrosis hátterében is gyulladásos, immunológiai folyamatok azonosíthatók. Ezek befolyásolásának egyik lehetősége az UC-II per os alkalmazása, amelynek segítségével oralis tolerancia hozható létre a 2-es típusú kollagénnel szemben, amely a porc egyik legjelentősebb alkotórésze. A gyulladáscsökkentés synovitisszel és porcdegenerációval járó kórképekben egyaránt hatásos, valamint az egészséges porcban is védő hatású a terheléssel kiváltott ízületi fájdalommal szemben. A tartós UC-II-kezelés reményteli lehetőség az arthrosis tartós betegségmódosító kezelésére, mivel ez a betegség megjelenése után élethosszig tart.

Anyagi támogatás: A szerző anyagi támogatásban nem részesült.

A cikk végleges változatát a szerző elolvasta és jóváhagyta.

Érdekeltségek: A szerzőnek nincsenek anyagi érdekeltségei.

\section{Irodalom}

[1] Horváth G, Koroknai G, Ács B, et al. Prevalence of knee osteoarthritis in Hungary. Study conducted in a representative Hungarian population. [Térdízületi arthrosis hazai előfordulása a déldunántúli betegpopuláción történt felmérés alapján.] Orv Hetil. 2010; 151: 140-143. [Hungarian]

[2] Cohen NP, Foster RJ, Mow VC. Composition and dynamics of articular cartilage: structure, function, and maintaining healthy state. J Orthop Sports Phys Ther. 1998; 28: 203-215.

[3] Glyn-Jones S, Palmer AJ, Agricola R, et al. Osteoarthritis. Lancet 2015; 386: 376-387.

[4] Loeser RF, Collins JA, Diekman BO. Ageing and the pathogen esis of osteoarthritis. Nat Rev Rheumatol. 2016; 12: 412-420.

[5] Courties A, Sellam J, Berenbaum F. Metabolic syndrome-associated osteoarthritis. Curr Opin Rheumatol. 2017; 29: 214-222.

[6] Veronese N, Cooper C, Reginster JY, et al. Type 2 diabetes mellitus and osteoarthritis. Semin Arthritis Rheum. 2019; 49: 9-19.

[7] Mobasheri A, Batt M. An update on the pathophysiology of osteoarthritis. Ann Phys Rehabil Med. 2016; 59: 333-339.

[8] Xia B, Di Chen, Zhang J, et al. Osteoarthritis pathogenesis: a review of molecular mechanisms. Calcif Tissue Int. 2014; 95 : 495-505

[9] Moran CJ, Pascual-Garrido C, Chubinskaya S, et al. Restoration of articular cartilage. J Bone Joint Surg Am. 2014; 96: 336-344. 
[10] Brand DD, Latham KA, Rosloniec EF. Collagen-induced arthritis. Nat Protoc. 2007; 2: 1269-1275.

[11] Tong T, Zhao W, Wu YQ, et al. Chicken type II collagen induced immune balance of main subtype of helper $\mathrm{T}$ cells in mesenteric lymph node lymphocytes in rats with collagen-induced arthritis. Inflamm Res. 2010; 59: 369-377.

[12] Park KS, Park MJ, Cho ML, et al. Type II collagen oral tolerance; mechanism and role in collagen-induced arthritis and rheumatoid arthritis. Mod Rheumatol. 2009; 19: 581-589.

[13] Trentham DE, Dynesius-Trentham RA, Orav EJ, et al. Effects of oral administration of type II collagen on rheumatoid arthritis. Science 1993; 261: 1727-1730.

[14] Bagchi D, Misner B, Bagchi M, et al. Effects of orally administered undenatured type II collagen against arthritic inflammatory diseases: a mechanistic exploration. Int J Clin Pharmacol Res. 2002; 22: 101-110.

[15] Ackerman I. Western Ontario and McMaster Universities Osteoarthritis Index (WOMAC). Aust J Physiother. 2009; 55: 213.

[16] Lequesne MG, Mery C, Samson M, et al. Indexes of severity for osteoarthritis of the hip and knee. Validation - value in compari- son with other assessment tests. Scand J Rheumatol. Suppl. 1987; 65: 85-89. [Erratum: Scand J Rheumatol. 1988; 17: 241.] [Erratum: Scand J Rheumatol Suppl. 1988; 73: 1.]

[17] Crowley DC, Lau FC, Sharma P, et al. Safety and efficacy of undenatured type II collagen in the treatment of osteoarthritis of the knee: a clinical trial. Int J Med Sci. 2009; 6: 312-321.

[18] Lugo JP, Saiyed ZM, Lane NE. Efficacy and tolerability of an undenatured type II collagen supplement in modulating knee osteoarthritis symptoms: a multicenter randomized, doubleblind, placebo-controlled study. Nutr J. 2016; 15: 14.

[19] Lugo JP, Saiyed ZM, Lau FC, et al. Undenatured type II collagen $\left(\mathrm{UC}-\mathrm{II}^{\circledR}\right)$ for joint support: a randomized, double-blind, placebo-controlled study in healthy volunteers. J Int Soc Sports Nutr. 2013; 10: 48.

(Sütő Gábor dr., Pécs, Pacsirta u. 1., 7624 e-mail: gabor.suto@immunologus.hu)

\section{"Consilii regimen virtuti corporis adde." (Testi erődet kormányozza az ész evezője.)}

A cikk a Creative Commons Attribution 4.0 International License (https://creativecommons.org/licenses/by/4.0/) feltételei szerint publikált Open Access közlemény, melynek szellemében a cikk bármilyen médiumban szabadon felhasználható, megosztható és újraközölhető, feltéve, hogy az eredeti szerző és a közlés helye, illetve a CC License linkje és az esetlegesen végrehajtott módositások feltüntetésre kerülnek. (SID_1) 